\title{
Adrenomedullin Functions as an Important Tumor Survival Factor in Human Carcinogenesis
}

\author{
FRANK CUTTITTA, ${ }^{1 *}$ RUBÉN PÍO ${ }^{2}$ MERCEDES GARAYOA,${ }^{3}$ ENRIQUE ZUDAIRE, ${ }^{1}$ MIGUEL JULIÁN, ${ }^{4}$ \\ TED H. ELSASSER, ${ }^{4}$ LUIS M. MONTUENGA, ${ }^{3}$ AND ALFREDO MARTINEZ ${ }^{1}$ \\ ${ }^{1}$ Cell and Cancer Biology Branch, Center for Cancer Research, National Cancer Institute, Bethesda, Maryland 20892, USA \\ ${ }^{2}$ Biochemistry Department, University of Navarra, Pamplona, Spain \\ ${ }^{3}$ Cellular and Pathology Department, University of Navarra, Pamplona, Spain \\ ${ }^{4}$ Growth Biology Laboratory, U.S. Department of Agriculture, Beltsville, Maryland 20705, USA
}

\author{
KEY WORDS cancer; apoptosis; angiogenesis; hypoxia; growth factor
}

\begin{abstract}
Adrenomedullin (AM) is a pluripotent regulatory peptide initially isolated from a human pheochromocytoma (adrenal tumor) and subsequently shown to play a critical role in cancer cell division, tumor neovascularization, and circumvention of programmed cell death, thus it is an important tumor cell survival factor underlying human carcinogenesis. A variety of neural and epithelial cancers have been shown to produce abundant amounts of AM. Recent findings have implicated elevation of serum AM with the onset of malignant expression. In addition, patients with tumors producing high levels of this peptide have a poor prognostic clinical outcome. Given that most human epithelial cancers display a microenvironment of reduced oxygen tension, it is interesting to note that AM and several of its receptors are upregulated during hypoxic insult. The existence of such a regulatory pathway has been implicated as the basis for the overexpression of AM/AM-R in human malignancies, thereby generating a subsequent autocrine/paracrine growth advantage for the tumor cell. Furthermore, AM has been implicated as a potential immune suppressor substance, inhibiting macrophage function and acting as a newly identified negative regulator of the complement cascade, protective properties which may help cancer cells to circumvent immune surveillance. Hence, AM's traditional participation in normal physiology (cited elsewhere in this issue) can be extended to a primary player in human carcinogenesis and may have clinical relevance as a biological target for the intervention of tumor progression. Microsc. Res. Tech. 57:110-119, $2002 . \quad$ Published 2002 Wiley-Liss, Inc. ${ }^{\dagger}$
\end{abstract}

\section{INTRODUCTION}

Adrenomedullin (AM) was originally identified in 1993 as a peptide isolated from a human endocrine tumor (pheochromocytoma), shown to stimulate adenylyl cyclase and to function as a vasodilator in vivo (Kitamura et al., 1993). This initial finding was rapidly followed by a series of discoveries which demonstrated AM to be a ubiquitous peptide found in a variety of tissues and operating as a crucial modulator of diverse physiological activities (Martínez and Cuttitta, 1998). AM is found in literally all organs of the body, from classic endocrine tissues (pituitary, adrenals, thyroid, pancreas, ovary, and testis), to anatomically distinct regions (brain, heart, lung, kidney, bladder, liver, thymus, spleen, and GI tract), to areas of the body giving support, movement, sensory, or protective capabilities (bone, cartilage, muscle, hair, and skin) (Martínez and Cuttitta, 1998). This peptide and immunologically related molecules have been found throughout the animal kingdom, represented in vertebrate (mammals, birds, reptiles, amphibians, and fish) and nonvertebrate (echinoderms) species (López et al., 1999; Martínez et al., 1996a). Based on this evolutionary conservation, extending over millions of years of animal adaptation, it is thought that AM plays a fundamental role in some aspect of species survival (Martínez and Cuttitta, 1998; Cuttitta et al., 1999). Supporting such thinking, AM has been demonstrated to be a pluripo- tent peptide modulating cardiovascular tone (Nuki et al., 1993; Ishiyama et al., 1993; Parkes, 1995), central brain activity (Murphy and Samson, 1995; Martínez et al., 1997a), bronchoelasticity (Kanazawa et al., 1994), hormone release (Samson et al., 1995; Martínez et al., 1996b), renal output (Ebara et al., 1994), apoptosis (Kato et al., 1997), angiogenesis (Zhao et al., 1998), cell growth (Cuttitta et al., 1999), and immune response (Kamoi et al., 1995; Kubo et al., 1998a; Allaker et al., 1999). These latter four functions are key components underlying the related growth processes of embryogenesis, wound repair, and carcinogenesis.

Rapid cell growth is a universal characteristic of fetal development, wound healing, and tumor progression. Over the past two decades of scientific study, it has become increasingly clear that factors which regulate growth in the normal setting are the same factors which modulate malignant cell proliferation (Nakamura and Matsumoto, 1994). In the normal configuration there are appropriate check-and-balance points

*Correspondence to: Frank Cuttitta, Cell and Cancer Biology Branch, Center for Cancer Research, National Cancer Institute, Building 10, Room 12N226, 9000 Rockville Pike, Bethesda, MD 20892. E-mail: cuttittf@mail.nih.gov

Received 9 August 2001; accepted in revised form 16 August 2001 DOI 10.1002/jemt.10059

Published online in Wiley InterScience (www.interscience.wiley.com). 
which allow for precise spatiotemporal control of cell growth, while in cancer regulation of growth cessation is corrupted (Hanahan and Weinberg, 2000). In the following we summarize our current understanding of AM's role in human carcinogenesis (promotion/invasion/metastasis) and demonstrate its potential use as a clinical target for the intervention of malignant disease.

\section{AM EXPRESSION IN HUMAN TUMOR TISSUE}

As previously stated, AM was first identified as a peptide product of a human adrenal tumor (pheochromocytoma) and has later been localized in a variety of neural and epithelial cancers. Satoh et al. (1995) reported that AM was not only expressed in different regions of the brain but also found in neural tumors such as ganglioneuroblastoma and neuroblastoma. In a related observation, Zimmermann et al. (1995) reported that a human neuroblastoma cell line, SK$\mathrm{N}-\mathrm{MC}$, could bind AM through what appeared to be the calcitonin gene-related peptide (CGRP) receptor and stimulate cAMP production. This was the first indication that a possible autocrine/paracrine mode of action could take place within tumor cells producing AM. The next anatomical cancer site to be established as a producer of AM was the lung. Using immunohistochemical and molecular techniques, Martínez et al. (1995) were able to demonstrate abundant expression of AM in airway epithelium and in cancer cell lines or tumors derived from this region (small cell carcinoma, adenocarcinoma, bronchioalveolar carcinoma, and carcinoids). As a further extension to this study, these same investigators found that a variety of human epithelial cancer cells derived from the lung, colon, breast, ovary, prostate, cartilage, and bone marrow could produce AM and express one of the putative AM receptors (AM-R) (Miller et al., 1996). In addition, they showed that AM could function as an autocrine growth factor for certain cancer cell lines and that a neutralizing monoclonal antibody to this ligand, MoAb-G6, could block this activity (Miller et al., 1996). Furthermore, it was noted that AM induced a cAMP response in cancer cell lines (Miller et al., 1996). Interestingly, a previous report by Withers et al. (1996) had demonstrated AM to be mitogenic for Swiss 3T3 mouse fibroblast cells via a cAMP-dependent pathway. These collective findings therefore implicated the AM/AM-R interactive autocrine system as a potential mechanism driving tumor proliferation in vivo.

Several subsequent articles have confirmed AM's proliferative function in cancer cells having diverse anatomical origins. The human melanoma cell line CRL-7585 was determined to express AM message/ protein and selectively bind ${ }^{125}$ I-labeled AM, which could not be inhibited with PAMP, $\mathrm{AM}_{22-52}$, CGRP, $\mathrm{CGRP}_{8-37}$, or amylin, thereby demonstrating ligand specificity (Martínez et al., 1997b). In addition, exogenous AM induced a dose-dependent stimulation of ${ }^{3} \mathrm{H}$ thymidine uptake by this skin cancer cell (Martínez et al., 1997b). Similarly, studies by Kapas et al. (1997) showed that exogenous AM could activate adenylyl cyclase in the oral squamous cell line H357, a signal transduction event which stimulated the growth of this cancer cell. This peptide-induced proliferative activity could be blocked by the adenylyl cyclase inhibitor, SQ22-536 or mimicked by the exogenous addition of the cell permeable cAMP analog dibutyryl cAMP (Kapas et al., 1997). In addition, those investigators found that the AM-mediated mitogenic response in H357 was not suppressed by inhibitors of the PKC or tyrosine kinase pathways, nor by the CGRP receptor antagonist $\mathrm{CGRP}_{8-37}$, demonstrating ligand and internal signaling specificity.

Research on glial cell tumors of the brain by Takahashi et al. (1997) from the Tohoku University School of Medicine, working with cell lines and pathological specimens, clearly demonstrate a potential autocrine involvement of AM in these cancers. AM mRNA and protein were found in the glioblastoma cell lines T98G and A172, while immunoreactive HPLC resolvable elements were detected in tissue from astrocytomas and glioblastomas (Takahashi et al., 1997). Interferon gamma (INF $\gamma$ ) and interleukin 1 beta (IL-1 $\beta$ ) treatment of T98G cells caused a dose-dependent increase in transcriptional/translational AM products, while tumor necrosis factor alpha $(\mathrm{TNF} \alpha)$ inhibited their expression (Takahashi et al., 1997). In addition, this group found that nanomolar concentrations of exogenous AM would augment adenylyl cyclase activity in T98G, implicating the possibility for an autocrine regulatory mechanism to exist in glioblastoma cells. In related experiments with the C6 rat glioma cell line, Moody et al. (1997) demonstrated that this tumor cell bound ${ }^{125} \mathrm{I}-\mathrm{AM}$ with high affinity $\left(\mathrm{K}_{\mathrm{d}}=24 \mathrm{nM}\right)$ and they determined by Scatchard analysis that the ligand binding takes place through a single class of sites with approximately 36,000 receptors per cell. Exogenous addition of AM to this rat glioma cell line caused a dosedependent increase in intracellular cAMP and a comparable increase in c-fos mRNA expression (Moody et al., 1997).

Interestingly, during the past several years a variety of clinical studies have begun to demonstrate an intimate involvement of AM with malignant disease. Initial testing by Ehlenz et al. (1997) showed elevated AM levels in the plasma of patients with lung and gastrointestinal cancers. Intraocular and orbital human tumors have been shown to have significantly higher AM mRNA expression $(P<0.05$ to $P<0.005)$ than similar anatomical tissue from nonmalignant disorders, including proliferative vitreoretinopathy, proliferative diabetic retinopathy, preretinal macular fibrosis, and acute retinal necrosis (Udono et al., 2000). Patients with Cushing's syndrome due to pituitary adenoma had markedly higher circulating AM levels than did normal controls and, following surgical excision of the tumor, AM concentrations dramatically decreased (Letizia et al., 2000). AM has been recently identified in leiomyomas, a common benign tumor of the uterus, and has been suggested to play an important role in stimulating neovascularization around the tumor body (Hague et al., 2000). Clinical observations by Hata et al. (2000), evaluating 60 cases of epithelial ovarian cancer, revealed that the level of AM gene expression detected in the tumor is significantly associated with histological grade and poor prognosis. In 20 cases of prostate cancer, a marked increase in AM mRNA expression was noted in tissue samples from patients having high Gleason's scores (Rocchi et al., 2000). From 
TABLE 1. AM/AM-R Expression in cancer cells and biological effect

\begin{tabular}{|c|c|c|c|c|}
\hline Pathology & Ligand & Receptor & Action & Reference \\
\hline \multicolumn{5}{|l|}{ Lung cancer } \\
\hline Small cell CA & + & + & n.d. & Martinez et al., 1995; Miller et al., 1996 \\
\hline Adeno CA & + & + & n.d. & Martinez et al., 1995; Miller et al., 1996 \\
\hline Large cell CA & + & + & n.d. & Martinez et al., 1995; Miller et al., 1996 \\
\hline Bronchioloalveolar CA & + & + & n.d. & Martinez et al., 1995; Miller et al., 1996 \\
\hline Squamous CA & + & + & Growth $\uparrow$ & Martinez et al., 1995; Miller et al., 1996 \\
\hline Carcinoid & + & + & Growth $\uparrow$ & Martinez et al., 1995; Miller et al., 1996 \\
\hline Colon cancer & + & + & n.d. & Nakayama et al., 1998; Miller et al., 1996 \\
\hline Breast cancer & + & + & cAMP $\uparrow /$ Growth $\uparrow$ & Miller et al., 1996 \\
\hline Ovarian cancer & + & + & Growth $\uparrow$ & Miller et al., 1996; Hata et al., 2000 \\
\hline Prostate cancer & + & + & Growth $\uparrow$ & Miller et al., 1996; Rocchi et al., 2001 \\
\hline \multicolumn{5}{|l|}{ Brain cancer } \\
\hline Glioblastoma & + & + & n.d. & Satoh et al., 1995 \\
\hline Neuroblastoma & + & + & cAMP $\uparrow /$ Growth $\downarrow$ & Cuttitta et al., 1999; Satoh et al., 1995 \\
\hline \multicolumn{5}{|l|}{ Skin cancer } \\
\hline Melanoma & + & + & Growth $\uparrow$ & Martínez et al., 1997 \\
\hline Oral squamous CA & + & + & $\mathrm{cAMP} \uparrow /$ Growth $\uparrow$ & Kapas et al., 1997 \\
\hline
\end{tabular}

Carcinoma, CA; $\uparrow$ stimulation; $\downarrow$ suppression; n.d., not done.

this cumulative clinical data it becomes increasingly clear that elevated AM expression is associated with a variety of human tumors and this ligand could potentially be used as a marker or intervention target of malignant disease. Table 1 is a summary of the anatomical types of cancer cells associated with AM/AM-R expression and the growth effect mediated by ligand/ receptor interaction.

\section{AM RECEPTORS AND SIGNAL TRANSDUCTION PATHWAYS}

Several receptors and a variety of signal transduction pathways have been associated with AM bioactivity (see accompanying articles of this issue). All of the receptors thus far identified have been members of a seven-transmembrane G-protein associated superfamily. Two of these receptors were identified/ characterized by the same investigative group, one denoted as L1, which had an exclusive binding recognition capability for AM, and the other RDC1, which selectively bound CGRP over AM (Kapas et al., 1995; Kapas and Clark, 1995). A third receptor system has been recently identified which represents a heterodimeric complex of the previously recognized moiety, calcitonin-receptor-like receptor (CRLR) and a newly established partner, receptor-activity-modifying proteins (RAMPs) (McLatchie et al., 1998). It has been determined that there are several RAMP molecules which specify ligand recognition and have the following binding pattern; CRLR + RAMP1 is selective for CGRP, while CRLR + RAMP2 or RAMP3 have selective recognition for AM. Ligand binding to L1, RDC1, or CRLR/RAMP complex mediates an elevated response in intracellular cAMP. The major intracellular signaling mechanism of AM appears to be cAMP, although $\mathrm{Ca}^{2+}$ mobilization, inositol 1,4,5-trisphosphate, protein kinase A (PKA), mitogen-activated protein kinase (MAPK), Max, phosphatidylinositol 3-kinase/Akt (PI3K/Akt), and cGMP have also been implicated (Kitamura et al., 1993; Withers et al., 1996; Kapas et al., 1997; Shimekake et al., 1995; Uezono et al., 1998; Shichiri et al., 1999; Semplicini et al., 2002; Nishimatsu et al., 2001). Given the respective receptor pedigrees and signal transduction pathways associated with AM biology, one could envision a multitude of intervention strategies targeted to disrupt ligand/receptor which could potentially have clinical applications in the treatment of cancer.

\section{INFLAMMATION AND HYPOXIA UPREGULATE AM EXPRESSION IN CANCER CELLS, DRIVING TUMOR GROWTH AND POTENTIALLY SUBVERTING IMMUNE SURVEILLANCE MECHANISMS}

Two major pathways recently recognized for their contributions to human carcinogenesis are the cellular processes of inflammation and hypoxic insult (Hanahan and Weinberg, 2000; Coussens and Werb, 2001; Balkwill and Mantovani, 2001; Brown and Giaccia, 1998; Zhong et al., 1999). Chronic inflammation has been shown to be one of the leading mechanisms underlying malignant transformation (Balkwill and Mantovani, 2001). Silica, asbestos, and cigarette smoking are major contributors to the onset of lung cancer, while papillomavirus and Helicobacter pylori infections increase the risk of cervical or gastric cancers, respectively (Balkwill and Mantovani, 2001). Leukocytic infiltrates in and around the tumor body have now been shown to release a variety of bioactive proteins (i.e., basic fibroblast growth factor [b-FGF], vascular endothelial growth factor [VEGF], monocyte chemotactic protein-1 [MCP-1], and matrix metalloproteinase-9 [MMP-9]) which can augment cancer cell growth and metastasis (Hanahan and Weinberg, 2000; Coussens and Werb, 2001). Similarly, low oxygen tension is known to upregulate the expression of several genes (i.e., transferrin, endothelin-1, and VEGF) important in maintaining cell viability during hypoxic insult (Wenger and Gassmann, 1997). Since most solid tumors have areas of regional hypoxia, the above-mentioned growth factors are enriched around the tumor body and thereby augment cancer cell growth (Brown and Giaccia, 1998; Zhong et al., 1999). In the following sections we discuss the role of AM in inflammation and hypoxia and how this relationship may contribute to human carcinogenesis. 


\section{AM and Inflammation}

There have been several reports in the scientific literature which implicate AM in inflammation. Initial studies by Sugo et al. $(1994,1995)$ showed that lipopolysaccharide (LPS) and the cytokines it induced to be released from activated lymphocytes/macrophages (IL-1 and TNF) stimulated AM production in rat vascular smooth muscle cells. A similar LPS/IL-1/TNF induced AM producing relationship has been demonstrated for rat endothelial cells (Isumi et al., 1998). In the rat model, intravenous injection of bacterial endotoxin resulted in augmentation of AM plasma levels and increased AM mRNA expression in the liver, heart, aorta, ileum, and kidney (Shoji et al., 1995). Along these same lines, clinical assessment of septic shock patients showed AM plasma concentrations which were 10-15 times higher than normal controls and AM urine levels that were elevated in children with urinary tract infections (Hirata et al., 1996; Dotsch et al., 1998). Given the accumulated evidence regarding AM responses to bacterial endotoxin in laboratory animals and humans, it becomes evident that this peptide may encompass some type of host protection against microbial pathogens. AM has recently been shown to have an antimicrobial-like ability, causing the lysis of bacterial and fungal organisms via membrane pore formation similar to other peptide defensins (Allaker et al., 1999, Zasloff, 1987; Walsh et al., 1996).

The ability of macrophages to produce AM in response to LPS, TNF, INF- $\gamma$, taxol, retinoic acid, and phorbol esters has been studied extensively (Kubo et al., 1998a, 1998b; Zaks-Zilberman et al., 1998). Using a murine macrophage cell line (RAW 246.7) immortalized with Abelson leukemia virus, Kubo et al. (1998a) have shown that AM could increase the basal secretion of TNF- $\gamma$ in this target cell, thus acting as an immune enhancer in this setting. Conversely, however, these same investigators have demonstrated that AM can suppress LPS-induced TNF- $\gamma$ and interleukin-6 secretion from RAW 246.7 cells. Such seminal studies imply that AM can act as an autocrine/paracrine regulator of the immune response mechanism. Thus, depending on the microcellular environment in which AM is introduced, it can function to augment or blunt the immune response capacity of macrophages. Experimental analysis of rat alveolar macrophages revealed the ability of AM to stimulate intracellular cAMP and block cytokine-induced neutrophil chemoattractant (CINC) release in a dose-dependent fashion, again confirming the suppressive effect that AM can have on macrophage function (Kamoi et al., 1995).

We have recently established human complement factor $\mathrm{H}$ (fH) as a serum binding protein for AM and that purified $\mathrm{fH}$ augments the ability of $\mathrm{AM}$ to induce cAMP response in Rat-2 fibroblast cells (Pío et al., 2001; for a review of this subject, see accompanying article in this issue). Complement $\mathrm{fH}$ is one of the key serum proteins responsible for the downregulation of complement mediated lysis (Pangburn and MüllerEberhard, 1983). It binds C3b, complexes with factor I (a proteinase), and rapidly degrades this key complement cascade protein, hence blocking complement lysis (Pangburn and Müller-Eberhard, 1983). We have shown that AM can cause a dose-dependent increase in the ability of the $\mathrm{fH} / \mathrm{fI}$ complex to proteolytically cleave C3b (Pío et al., 2001). Recent studies with the human H2 glioblastoma cell line have shown that cancer cells can produce $\mathrm{fH}$, and in so doing become extremely resistant to complement mediated lysis (Junnikkala et al., 2000; Fedarko et al., 2000). Hence, human tumor cells producing both $\mathrm{fH}$ and AM would potentially have a selective capacity to circumvent immune surveillance via enhanced suppression of the complement cascade pathway.

Based on the previously outlined involvement of AM in inflammation that includes the ability of endotoxins/ cytokines to augment AM mRNA expression, the capacity of AM to suppress cytokine release from activated leukocytic target cells and the potential inhibitory role AM plays in complement lysis, an overwhelming amount of information has been compiled which suggests that AM may function as a tumor protection factor assisting cancer cells to evade immune surveillance mechanisms.

\section{Hypoxia Upregulates AM/AM-R Expression}

Initial studies by the Hammersmith group in the UK demonstrated that environmental exposure to 7-day chronic hypoxia in experimental rats did not augment AM mRNA or protein expression in the lung (Zhao et al., 1996). Unfortunately, no serum level data was available from this study. Interestingly, this group reported that the upper airway binding of ${ }^{125} \mathrm{I}-\mathrm{AM}$ and ${ }^{125}$ I-CGRP dramatically increased over the 7-day period of reduced oxygen tension, indicating the possibility of hypoxia-mediated AM/CGRP receptor upregulation. This preliminary finding was eventually confirmed by other laboratories 5 years later (Ladoux and Frelin, 2000; Qing et al., 2001). The first report in the literature which actually linked hypoxia to AM expression was that of Wang et al. (1995), who demonstrated dramatic increases in AM mRNA levels (17.4-fold to 21.7-fold enhancement of message) when studying ischemic insult in the brain of experimental rats using differential display analysis. These investigators also found augmented immunohistochemical staining for $\mathrm{AM}$ at the site of the ischemic lesion, implying that hypoxic stress could upregulate both transcriptional and translational products of this gene. Subsequent studies on patients and animals with heart failure showed similar results, revealing enhanced AM plasma concentrations mediated by diminished cardiovascular oxygen tension (Kato et al., 1996; Nishikimi et al., 1997; Jougashaki et al., 1997). Similarly, Cheung and Leung (1997) described elevated plasma levels of the peptide in patients with chronic obstructive pulmonary disease (COPD) with hypoxia. These investigators suggested the observed increased levels of plasma AM in COPD patients were due to a compensatory response by the host to enhance blood flow via peptide-induced vasodilation. Another early study implicating hypoxia as an upregulator of AM expression was performed on high-altitude mountaineers (Toepfer et al., 1998). Male and female volunteers were evaluated as to their respective AM plasma levels following high-altitude ascent by comparing values measured at $1,782 \mathrm{ft}$ (basal) to that observed at $15,048 \mathrm{ft}$ (test), which showed clear statistical differences between the two figures. One major concern about this study is that no consideration 
was given to the role of exercise-induced AM expression when screening the mountaineers for their presumptive hypoxia-mediated change in blood peptide levels. Strenuous exercise had been previously shown to augment AM plasma concentrations (Tanaka et al., 1995; Piquard et al., 2000) and in the mountaineer study, subjects underwent a 5-hour climb to achieve their endpoint test altitude, thus potentially tainting the data. It was not until several years later that researchers began to establish a relationship between hypoxia, AM, and carcinogenesis.

A study by Nakayama et al. (1998) was the first report to clearly demonstrate the modulatory relationship hypoxia had on AM expression in human tumor cells. These investigators exposed human colorectal carcinoma cells (DLD-1) to low oxygen tension, which in turn caused a rapid time-dependent increase in AM message expression, accompanied by a similar increase of detectable immunoreactive peptide in the conditioned medium. In addition, they showed that the heavy metal $\mathrm{CoCl}_{2}$, a hypoxia mimetic, also caused a parallel time-dependent increase in AM mRNA/protein levels. HPLC purification techniques were used to validate the authenticity of the immunoreactive peptide found in the conditioned media as native AM. Finding no hypoxia response elements (HRE) in the $5^{\prime}$ upstream flanking region of the human AM gene (the DNA binding site for the transcription factor hypoxia inducible factor-1, HIF-1) (Wenger and Gassmann, 1997), Nakayama et al. (1998) suggested that an alternative molecular mechanism was possibly involved in their observed oxygen regulated AM expression. Since the $5^{\prime}$ promoter region of the AM gene contains two AP-1 sites, they proposed that hypoxia upregulation of c-fos and c-jun drives the formation of the heterodimer AP-1, which in turn functions as the primary transcription factor controlling AM expression at low oxygen tension (Misha et al., 1998). In contrast to this thinking, our group and others have shown that hypoxiainduced AM expression is governed by the interaction of HIF-1 with a variety of interactive sites along the AM promoter (Cormier-Regard et al., 1998; Garayoa et al., 2000).

One of the classic molecular mechanisms modulating gene expression as a result of diminished oxygen tension (i.e., $<2 \% \mathrm{O}_{2}$ ) is dependent on genomic interaction with the HIF-1 transcription factor (Wenger and Gassmann, 1997). HIF-1 is composed of two protein component subunits, HIF- $1 \alpha$ and HIF-1 $\beta$ (Wenger and Gassmann, 1997). The transcription/translation products of both heterodimer partners are constitutively expressed; however, the HIF-1 $\alpha$ protein contains an oxygen-dependent degradative domain that is rapidly cleaved by the ubiquitin-proteasome pathway under normoxic conditions, thus enabling the modulation of HIF-1 activity in an oxygen-dependent manner (Huang et al., 1998). Recently, it has been shown that the protein product of von Hippel-Lindau (VHL) tumor suppressor gene binds to HIF-1 $\alpha$ and mediates its ubiquitination/proteosomal degradation under normoxic conditions (Tanimoto et al., 2000). Interestingly, mutations in VHL can lead to cell transformation and tumor development, in part caused by the elevation of HIF$1 \alpha$, which in turn drives hypoxia-regulated gene expression products such as the angiogenesis factor
VEGF to be actively generated (Kondo and Kaelin, 2001). Many human tumors have been shown to have elevated HIF- $1 \alpha$ via a variety of molecular mechanisms (hypoxia, mutational VHL, etc.) and thus have a predisposition for neovascularization events to occur which augments cancer progression (Zhong et al., 1999). AM is one of the modulatory genes upregulated in normal and cancer cells as a result of HIF-1 $\alpha$ elevation, which in turn conveys a selective growth bias to their host cells (Cormier-Regard et al., 1998; Garayoa et al., 2000).

Investigative studies generated in William Claycomb's group from Louisiana State University Medical Center were the first published reports to establish the existence of a HIF-1 regulatory mechanism controlling AM expression in cardiomyocytes (Cormier-Regard et al., 1998; Nguyen and Claycomb, 1999). Using differential display and RT-PCR, they showed that AM mRNA expression in the adult ventricular cardiac muscle was 4-fold higher than that observed for its counterpart tissue in E17 embryonic rat. Exposure of adult rat ventricular cardiac myocytes to hypoxic conditions $\left(1 \% \mathrm{O}_{2}\right)$ caused a time-dependent increase in AM message expression which at 12 hours was 2.2 -fold greater than the corresponding normoxic control time point. These investigators identified two tentative base motifs in the $5^{\prime}$ promoter region of the mouse AM gene $(-1095 \mathrm{bp}$ and $-770 \mathrm{bp}$ from the transcriptional start site) which were similar in sequence to previously reported HREs for other HIF-1 regulated genes (VEGF, erythropoietin, and lactate dehydrogenase). When the $5^{\prime}$ promoter of mouse AM was linked to a luciferase reporter, upregulation of enzyme expression was detected under hypoxic conditions. Site-directed mutagenesis demonstrated that the -1095 bp motif was the main HRE component responsible for hypoxiainduced luciferase activity. To prove that this potential HRE site would actually bind HIF-1, an 18-bp doublestranded oligonucleotide $\left[{ }^{32} \mathrm{P}\right]$ labeled probe was produced containing the $-1095 \mathrm{bp}$ motif. When this probe was mixed with the nuclear extract from hypoxiatreated myocytes, a positive gel shift response was observed, indicating HIF-1 complex formation. The nuclear extract from normoxic myocytes or mutated probe failed to demonstrate complex formation. Hence, this group's combined studies generated clear evidence of an AM/HIF-1 regulatory loop existing in myocytes.

Our laboratory has also shown that a similar AM/ HIF-1 regulatory component is in place for a variety of human epithelial cancer cell lines and that this relationship may convey a selective growth advantage to the tumor cell during carcinogenesis (Garayoa et al., 2000). We have demonstrated, using Northern analysis, that exposure to hypoxia or hypoxia mimetics (desferrioxamine mesylate [DFX] and cobalt chloride $\left.\left[\mathrm{CoCl}_{2}\right]\right)$ can dramatically increase AM message (2-20fold)/protein (3-fold) expression in cancer cells (Fig. 1). Irrespective of their tissue of origin (carcinomas of the lung, breast, colon, prostate, and ovary), all of our hypoxia-treated cancer cell lines responded with a marked increase in AM mRNA expression. Hypoxia time-course studies revealed that enhanced AM transcript production was detected as early as 4 hours after exposure to reduced oxygen tension, maximized at 12 hours and maintained a maximal response following 


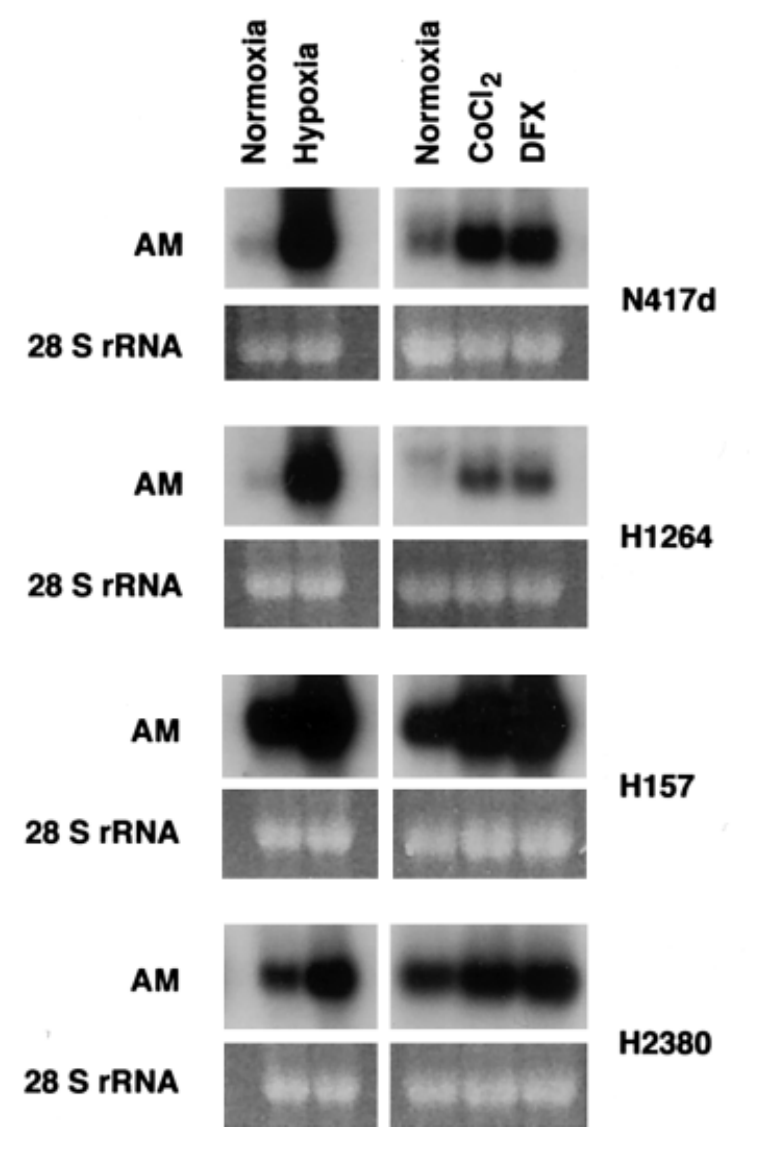

Fig. 1. Upregulation of AM mRNA in several human tumor cell lines under hypoxic or hypoxia mimetic treatment. Northern blot analysis for AM on cells exposed either to hypoxia mimetics $(100 \mu \mathrm{M}$ $\mathrm{CoCl}_{2}$ or $260 \mu \mathrm{M}$ DFX) for 6 hours, or to a hypoxic atmosphere $\left(1 \% \mathrm{O}_{2}\right.$, $5 \% \mathrm{CO}_{2}$, and $94 \% \mathrm{~N}_{2}$ ) for 12 hours, as compared with untreated cells. Cell lines shown here were selected from a total of 17 cell lines tested and also chosen as representatives of the main human tumor types:

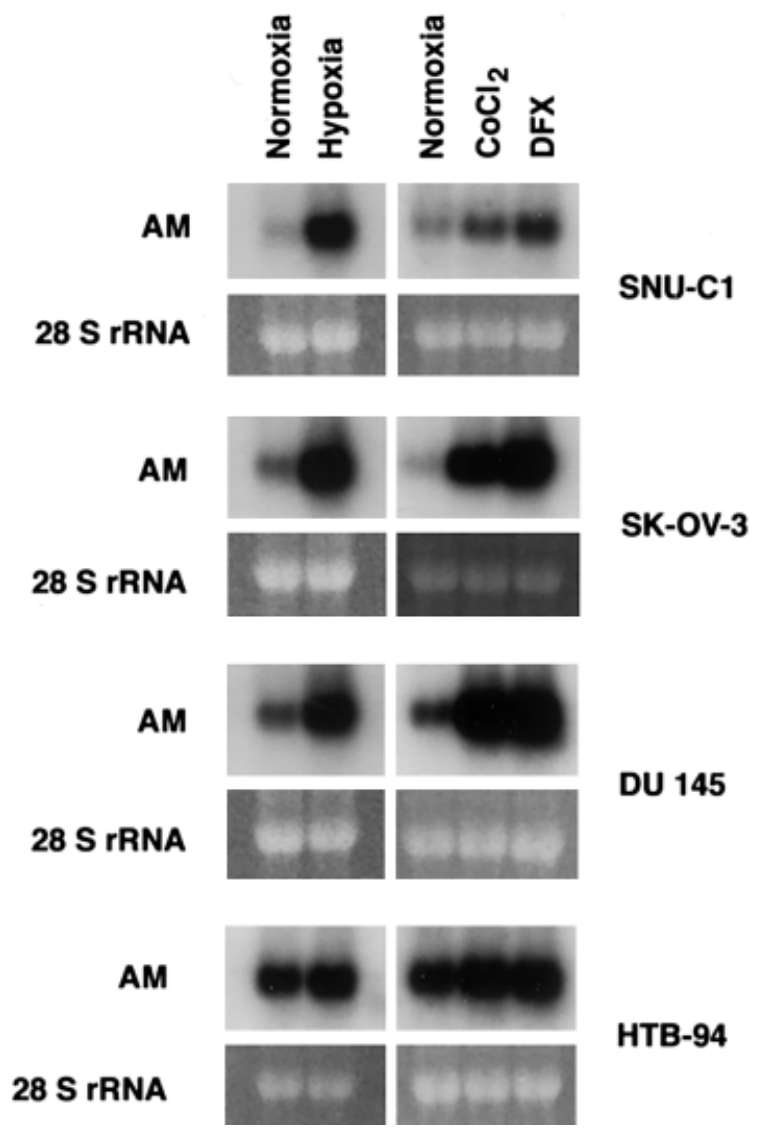

carcinoma (CA) of the lung (N417 [small cell CA], H1264 [adeno CA], H157 [squamous CA]), breast CA (H2380), colon CA (SNUC-1), ovarian CA (SK-OV-3), prostate CA (DU145), and chondrosarcoma (HTB94). Fifteen micrograms of total RNA were loaded per lane and ethidium bromide staining of $28 \mathrm{~S}$ rRNA was used to check for equal loading and RNA integrity. (Reprinted with permission, Molecular Endocrinology, Garayoa et al., 2000.)
48 hours of treatment (Fig. 2). The interdependency of an intact HIF-1 molecule on hypoxia-induced AM expression was demonstrated using immortalized embryonic mouse cells from HIF- $1 \alpha$ or HIF-1 $\beta$ knockout mice. Using HIF- $1 \alpha / \mathrm{HIF}-1 \beta$ null mice fibroblast/stem cells, we have shown the absolute requirement for a functional HIF-1 transcription factor to drive hypoxia- or hypoxia mimetic-induced upregulation of AM mRNA (Garayoa et al., 2000). We have also determined that RNA stabilization is in part responsible for the enhanced AM mRNA expression observed following hypoxia treatment of human cancer cells (Garayoa et al., 2000). In the human AM gene (GenBank accession No. D43639), we have identified 20 potential HRE sites distributed through the molecular structure, including motifs within the $5^{\prime}$ promoter, the $3^{\prime}$-flanking region, introns/exons and readable on both sense and antisense strands. Reporter studies in MCF-7 (breast cancer cell line) with select HREs were capable of enhancing luciferase activity following exposure to DFX and transient coexpression of $\mathrm{HIF}-1 \alpha$ resulted in an augmented transactivation of the reporter gene after DFX treatment, thus further supporting the role of HIF-1 in this hypoxia-induced event. As a final inference to our collective studies in this area, we postulate that HIF1-regulated AM expression may be a critical pathway in human carcinogenesis, given that most solid tumors are hypoxic by nature and that AM can function as an important survival factor (stimulating tumor growth, driving regional neovascularization, suppressing programmed cell death, and evading immune surveillance).

Over the last 3 years several laboratories have now confirmed the ability of hypoxic exposure to upregulate AM expression in a diverse number of normal human, rodent, and canine cells. Short-term cultures of human coronary artery endothelial cells, umbilical vein endothelial cells (HUVEC), and retinal pigment epithelial cells have been shown to respond in this manner (Nakayama et al., 1999; Ogita et al., 2001; Udono et al., 2001). The studies performed by Ogita et al. (2001) on HUVEC not only confirmed that reduced oxygen tension increased the half-life of AM message but that it also enhanced gene transcription rate, as determined by nuclear run-off analysis. Hypoxia-induced augmentation of AM expression has also been observed in 


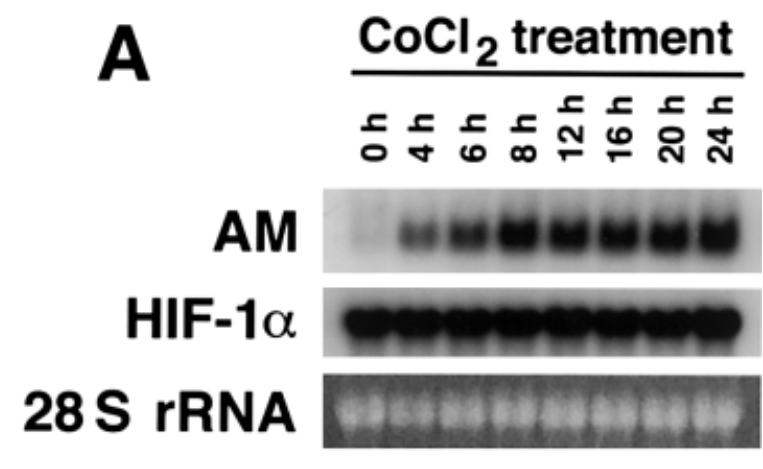

B DFX treatment

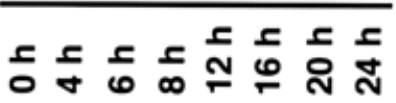

AM

28 S rRNA
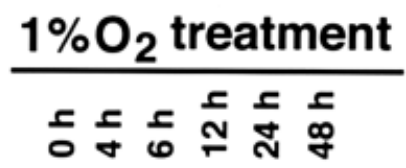

\section{AM \\ HIF-1 $\alpha$ \\ 28 S rRNA}
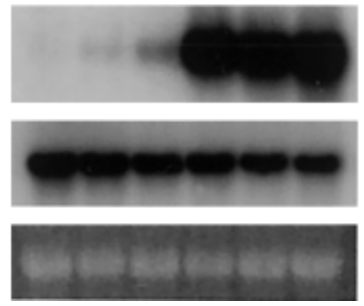

Fig. 2. Time course analysis of AM expression. Northern blot analysis of MCF-7 (breast CA) cells cultured under $100 \mu \mathrm{M} \mathrm{CoCl}_{2}(\mathbf{A})$, $260 \mu \mathrm{M}$ DFX (B), or $1 \% \mathrm{O}_{2}(\mathbf{C})$ for the indicated times. Fifteen micrograms of total RNA were loaded per lane and hybridized subsequently with human AM and human HIF-1 $\alpha$ cDNA probes. Equal loading was monitored by ethidium bromide staining of $28 \mathrm{~S}$ rRNA for each blot. (Reprinted with permission, Molecular Endocrinology, Garayoa et al., 2000.)

canine kidney cells, rat vascular smooth muscle cells, and rat mesangial cells (Nagata et al., 1999). Recent in vivo experiments on hypoxic rats have revealed that transcription/translation for AM and AM-R dramatically increases in lung tissue as compared to levels observed in the normoxic animal (Hofbauer et al., 2000; Qing et al., 2001). These pulmonary responses can be simulated by inhalation of carbon monoxide (CO) or by subcutaneous challenge with cobalt chloride (Hofbauer et al., 2000). Given the fact that cigarette smokers are at high risk of developing lung cancer, it is interesting to note that smoking can cause pulmonary hypoxia and elevate CO levels in the upper/distal airway. Do such anatomical events ultimately lead to elevated lung AM/ AM-R levels in humans and, if so, is this one of the underlying causes by which individuals become predisposed to malignant transformation? Hopefully, over the next several years these questions can be properly addressed and the resulting answers increase our understanding of AM's role in cancer.

\section{AM AS A SURVIVAL FACTOR IN HUMAN CARCINOGENESIS}

In the Introduction, we assigned four functional attributes to AM which could selectively enhance the growth of tumor cells during the carcinogenesis process. These proliferative characteristics include the ability of AM to function as a direct mitogen, its capacity to act as an inhibitor of programmed cell death, its potential to stimulate neovascularization, and its ability to suppress the immune response (Kato et al., 1997; Zhao et al., 1998; Kamoi et al., 1995; Kubo et al., 1998a; Miller et al., 1996).

We have previously reviewed our work with human tumor cell lines, where we showed that a variety of anatomically distinct cancer cell lines possess an AM/ AM-R autocrine/paracrine loop capable of augmenting tumor cell growth in vitro. This proliferative mechanism could be effectively blocked with a neutralizing monoclonal antibody, MoAb-G6, in a dose-dependent fashion (Miller et al., 1996). We have recently applied this same strategy to nude mouse xenografts and have found that MoAb-G6 can significantly suppress tumor growth (breast CA and bronchioloalveolar CA) in this animal model when compared to results for an isotypic control treatment group (unpublished observation). This is actually the first preclinical information that implies the usefulness of anti-AM reagents as being appropriate for therapeutic intervention in cancer.

The initial work by Kato et al. (1997) which identified AM as an autocrine/paracrine apoptosis survival factor for rat endothelial cells was a landmark study which opened up the possibility that a similar relationship may exist in tumor cells (Cuttitta et al., 1999; Garayoa et al., 2000). These investigators have also shown that AM inhibition of programmed cell death in rat endothelial cells was mediated through a cAMPindependent pathway (Kato et al., 1997). Follow-up experiments by Hirata's group (Shichiri et al., 1999) showed that AM suppression of apoptosis via serum deprivation in rat aortic endothelial cells was mediated through the upregulation of Max basic-helix-loop-helixleucine zipper protein. Normally, Max forms a heterodimer with c-Myc and the resulting complex functions as a transcription factor binding to the E-box recognition site (CACGTG), thus stimulating cell proliferation or apoptosis (Blackwell et al., 1993). It has been proposed by Hirata's group that when Max is overexpressed in endothelial cells treated with AM, Max-Max homodimers are formed which lack transcriptional activation domain and repress Myc-Max formation/function, thus resulting in a blockage of programmed cell death. The ability of Max-Max complex to act as a dominant negative inhibitor of Myc-Maxinduced transcription was shown by Shichiri et al. (1999) using a preproendothelin-1 promoter containing 


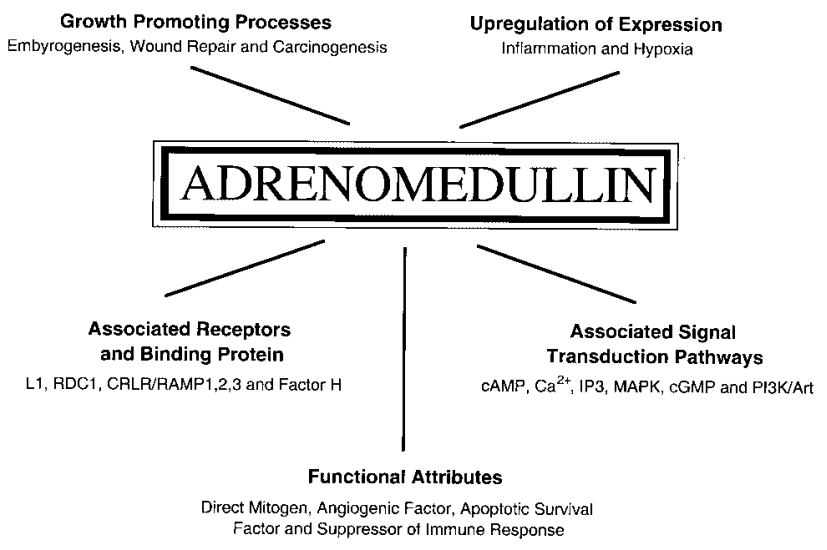

Fig. 3. Summary chart of the growth regulatory role AM has in carcinogenesis and related proliferative processes (embryogenesis and wound repair). Listing the major control mechanisms modulating its expression, citing its known receptors and binding protein moieties, its signal transduction pathways, and its inherent biological functions that may contribute to tumor promotion.

the Myc-Max bind consensus sequence. They observed a diminution in promoter activity when cotransfecting with Max- and Mad-expressing plasmids. Promoter activation was also blocked by the addition of AM or CGRP. In addition, Max antisense oligonucleotides were shown to abrogate AM-mediated inhibition of endothelial cell apoptosis.

Finally, AM has been proven to be an angiogenic factor capable of stimulating neovascularization in the chick chorioallantoic membrane (CAM) assay at nanogram concentrations with similar potency to b-FGF (Zhao et al., 1998). These investigators have also shown that AM can induce the cell growth of freshly isolated HUVECs in culture. As previously mentioned, Rees's laboratory has shown that AM expression in uterine leiomyoma correlates with vascular density of the tumor (Hague et al., 2000). Recently, the same group used a steroid-sensitive endometrial carcinoma cell line (Ishikawa) to demonstrate that hypoxia induced AM production upregulated Bcl-2 expression, which in turn protected the cancer cell from apoptosis caused by low oxygen insult (Oehler et al., 2001). Ishikawa cells were shown to have CRLR/RAMP2 receptors and the exogenous addition of AM caused a dosedependent inhibition of hypoxia-induced apoptosis in this carcinoma cell line. In addition, Ishikawa cells stably transfected with AM overexpressed Bcl-2 and were resistant to hypoxia-mediated cell death. These investigators suggest that the combined biological characteristics of AM, stimulator of angiogenesis and suppressor of programmed cell death, serve to promote the carcinogenesis pathway.

\section{CONCLUSION}

We have tried to give a collective overview of what is known about the role of AM in human carcinogenesis. Clearly, in the past 8 years since its initial discovery, AM has been shown to have several intriguing biological characteristics and mediate a variety of cellular responses which would promote tumor cell growth (Fig. 3 ). Cancer cells expressing AM/AM-R have the poten- tial for an autocrine/paracrine mechanism of growth promotion, as summarized in Table 1. Inflammation and hypoxia appear to be the most consistent inducers of AM/AM-R expression associated with malignant disease. AM has been demonstrated to be a direct mitogen, functioning as a stimulator of neovascularization and a suppressor of programmed cell death. Such biological attributes are thought to play a critical role in tumor development and hence represent rational targets to devise intervention strategies for use in the clinical arena.

\section{REFERENCES}

Allaker RP, Zihni C, Kapas S. 1999. An investigation into the antimicrobial effects of adrenomedullin on members of the skin, oral respiratory tract and gut microflora. FEMS Immunol Med Microbiol 23:289-293.

Balkwill F, Mantovani A. 2001. Inflammation and cancer: back to Virchow? Lancet 357:539-545.

Blackwell TK, Huang J, Ma A, Kretzner L, Alt FW, Eisenman RN, Weintraub H. 1993. Binding of myc protein to canonical and noncanonical DNA sequences. Mol Cell Biol 13:5216-5224.

Brown JM, Giaccia AJ. 1998. The unique physiology of solid tumors: opportunities (and problems) for cancer therapy. Cancer Res 58: 1408-1416.

Cheung B, Leung R. 1997. Elevated plasma levels of human adrenomedullin in cardiovascular, respiratory, hepatic and renal disorders. Clin Sci (Colch) 92:59-62.

Cormier-Regard S, Nguyen SV, Claycomb WC. 1998. Adrenomedullin gene expression is developmentally regulated and induced by hypoxia in rat ventricular cardiac myocytes. J Biol Chem 273:1778717792 .

Coussens LM, Werb Z. 2001. Inflammatory cells and cancer: think different! J Exp Med 193:F23-F26.

Cuttitta F, Montuenga LM, Garayoa M, Pío R, Miller JM, Walsh T, Elsasser T, Martínez A. 1999. The role of adrenomedullin as a growth regulatory peptide in the normal and malignant setting. J Anim Sci 77(Suppl 3):55-69.

Dotsch J, Hanze J, Knufer V, Steiss JO, Dittrich K, Seidel A, Rascher W. 1998. Increased urinary adrenomedullin excretion in children with urinary tract infection. Nephrol Dial Transpl 13:1686-1689.

Ebara T, Miura K, Okumura M, Matsuura T, Kim S, Yukimura T, Iwao H. 1994. Effect of adrenomedullin on renal hemodynamics and function in dogs. Eur J Pharmacol 263:F657-F663.

Ehlenz K, Koch B, Preuss P, Simon B, Koop I, Lang RE. 1997. High levels of circulating adrenomedullin in severe illness: correlation with C-reactive protein and evidence against the adrenal medulla as site of origin. Exp Clin Endocrinol Diabetes 105:156-162.

Fedarko NS, Fohr B, Robey PG, Young MF, Fisher LW. 2000. Factor $\mathrm{H}$ binding to bone sialoprotein and osteopontin enables tumor cell evasion of complement-mediated attack. J Biol Chem 275:1666616672 .

Garayoa M, Martínez A, Lee S, Pío R, An WG, Neckers L, Trepel J, Montuenga LM, Ryan H, Johnson R, Gassmann M, Cuttitta F. 2000. Hypoxia-inducible facrtor-1 (HIF-1) up-regulates adrenomedullin expression in human tumor cell lines during oxygen deprivation: a possible promotion mechanism of carcinogenesis. Mol Endocrinol 14:848-862.

Hague S, Zhang L, Oehler MK, Manek S, MacKenzie IZ, Bickell R, Rees MC. 2000. Expression of the hypoxically regulated angiogenic factor adrenomedullin correlates with uterine leiomyoma vascular density. Clin Cancer Res 6:2808-2814.

Hanahan D, Weinberg RA. 2000. The hallmarks of cancer. Cell 100: 57-70.

Hata K, Takebayashi Y, Akiba S, Fujiwaki F, Iida K, Nakayama K, Nakayama S, Fukumoto M, Miyazaki K. 2000. Expression of the adrenomedullin gene in epithelial ovarian cancer. Mol Hum Reprod 6:867-872.

Hirata Y, Mitaka C, Sato K, Nagura T, Tsunoda Y, Amaha K, Marumo F. 1996. Increased circulation adrenomedullin, a novel vasodilatory peptide, in sepsis. J Clin Endocrinol Metab 81:1449-1453.

Hofbauer K-H, Jensen BL, Kurtz A, Sander P. 2000. Tissue hypoxygenation activates the adrenomedullin system in vivo. Am J Physiol (Regul Integr Comp Physiol) 278:R513-R519.

Huang LE, Gu J, Schau M, Bunn HF. 1998. Regulation of hypoxiainducible factor $1 \alpha$ is mediated by an 02-dependent degradation domain vial the ubiquitin-proteasome pathway. Proc Natl Acad Sci USA 95:7987-7992. 
Ishiyama Y, Kitamura K, Ichiki Y, Nakamura S, Kida O, Kangawa K, Eto Y. 1993. Hemodynamic effects of a novel hypotensive peptide, human adrenomedullin, in rats. Eur J Pharmacol 241:271-273.

Isumi Y, Shoji H, Sugo S, Tochimoto T, Yoshioka M, Kangawa K, Matsuo H, Minamino N. 1998. Regulation of adrenomedullin production in rat endothelial cells. Endocrinology 139:838-846.

Jougashaki M, Stevens TL, Borgeson DD, Luchner A, Redfield MM, Burnett Jr JC. 1997. Adrenomedullin in experimental congestive heart failure: cardiorenal activation. Am J Physiol (Regulat Integr Comp Physiol) 273:R1392-R1399.

Junnikkala S, Jokiranta TS, Friese MA, Jarva H, Zipfel PF, Meri S. 2000. Exceptional resistance of human H2 glioblastoma cells to complement-mediated killing by expression and utilization of factor $\mathrm{H}$ and factor H-like protein 1. J Immunol 164:6075-6081.

Kamoi H, Kanazawa H, Hirata K, Kurihara N, Yano Y, Otani S. 1995. Adrenomedullin inhibits the secretion of cytokine-induced neurtophil chemoattractant, a member of the interleukin-8 family, from rat alveolar macrophages. Biochem Biophys Res Commun 211:1031-1035.

Kanazawa H, Kurihara N, Hirata K, Kudoh S, Kawaguchi T, Takeda T. 1994. Adrenomedullin, a newly discovered hypotensive peptide, is a potent bronchodilator. Biochem Biophys Res Commun 205:251254.

Kapas S, Clark AJL. 1995. Identification of an orphan receptor gene as a type 1 calcitonin gene-related peptide receptor. Biochem Biophys Res Commun 217:832-838.

Kapas S, Catt KJ, Clark AJL. 1995. Cloning and expression of cDNA encoding a rat adrenomedullin receptor. J Biol Chem 270:2534425347.

Kapas S, Brown DW, Fathing PM, Hgi-Pavli E. 1997. Adrenomedullin has mitogenic effects on human oral keratinocytes: involvement of cyclic AMP. FEBS Lett 418:287-290.

Kato J, Kobayashi K, Etoh T, Tanaka M, Kitamura K, Imamura T, Koiwaya Y, Kangawa K, Eto T. 1996. Plasma adrenomedullin concentration in patients with heart failure. J Clin Endocrinol Metab 81:180-183

Kato H, Shichiri M, Marumo F, Hirata Y. 1997. Adrenomedullin as an autocrine/paracrine apoptosis survival factor for rat endothelial cells. Endocrinology 138:2615-2620.

Kitamura K, Kangawa K, Kawamoto M, Ichiki Y, Nakamura S, Matsuo H, Eto T. 1993. Adrenomedullin: a novel hypotensive peptide isolated from human pheochromocytoma. Biochem Biophys Res Commun 192:553-560.

Kondo K, Kaelin WG. 2001. The von Hippel-Lindau tumor suppressor gene. Exp Cell Res 264:117-125.

Kubo A, Minamino N, Isumi Y, Katafuchi T, Kangawa K, Dohi K, Matsuo H. 1998a. Production of adrenomedullin in macrophage cell lines and peritoneal macrophage. J Biol Chem 237:16730-16738.

Kubo A, Minamino N, Isumi Y, Kangawa K, Dohi K, Matsuo H. 1998b. Adrenomedullin production is correlated with differentiation in human leukemia cell lines and peripheral blooc monocytes. FEBS Lett 426:233-237.

Ladoux A, Frelin C. 2000. Coordinated up-regulation by hypoxia of adrenomedullin and one of its putative recepotrs (RDC-1) in cells of the rat blood-brain barrier. J Biol Chem 275:39914-39919.

Letizia C, Di Iorio R, De Toma G, Marinoni E, Cerci S, Celi M, Subioli S, D'Erasmo E. 2000. Circulating adrenomedullin is increased in patients with corticotropin-dependent Cushing's syndrome due to pituitary adenoma. Metabolism 49:760-763.

López J, Cuesta N, Cuttitta F, Martínez A. 1999. Adrenoemdullin in nonmammalian vertebrates pancreas: an immunocytochemical study. Gen Comp Endocrinol 115:309-322.

Martínez A, Cuttitta F. 1998. Adrenomedullin. Amsterdam: IOS Press/Ohmsha.

Martínez A, Miller MJ, Unsworth EJ, Siegfried JM, Cuttitta F. 1995. Expression of adrenomedullin in normal lung and in pulmonary tumors. Endocrinology 136:4099-4105.

Martínez A, Unsworth EJ, Cuttitta F. 1996a. Adrenomedullin-like immunoreactivity in the nervous system of the starfish Marthasterias glacialis. Cell Tissue Res 283:169-172.

Martínez A, Weaver C, López J, Bhathena SJ, Elasser TH, Miller MJ, Moody TW, Unsworth EJ, Cuttitta F. 1996b. Regulation of insulin secretion and blood glucose metabolism by adrenomedullin. Endocrinology 136:2626-2632.

Martínez V, Cuttitta F, Taché Y. 1997a. Central action of adrenomedullin to inhibit gastric emptying in rats. Endocrinology 138:3749-3755.

Martínez A, Elsasser TH, Muro-Cacho C, Moody TW, Miller MJ, Macri CJ, Cuttitta F. 1997b. Expression of adrenomedullin and its receptor in normal and malignant human skin: a potential pluripotent role in the integument. Endocrinology 138:5597-5604.
McLatchie LM, Fraser NJ, Main MJ, Wise A, Brown J, Thompson N, Solari R, Lee MG, Foord SM. 1998. RAMPs regulate the transport and ligand specificity of the calcitonin-receptor-like receptor. Nature 393:333-339.

Miller MJ, Martínez A, Unsworth EJ, Thiele CJ, Moody TW, Elsasser T, Cuttitta F. 1996. Adrenomedullin expression in human tumor cell lines. Its potential role as an autocrine growth factor. J Biol Chem 271:23345-23351.

Mishra RR, Adhikary G, Simonson MS, Cherniack NS, Prabhakar NR. 1998. Role of c-fos in hypoxia-induced AP-1 cis-element activity and tyrosine hydrolyase gene expression. Brain Res Mol Brain Res 59:74-83.

Moody TW, Miller MJ, Martínez A, Unsworth E, Cuttitta F. 1997. Adrenomedullin binds with high affinity, elevates cyclic AMP, and stimulates c-fos mRNA in C6 glioma cells. Peptides 18:111-1115.

Murphy TC, Samson WK. 1995. The novel vasoactive hormone, adrenomedullin, inhibits water drinking in the rat. Endocrinology 136:2459-2463.

Nagata D, Hirata Y, Suzuki E, Kakoki M, Hayakawa H, Goto A, Ishimitsu T, Minamino N, Ono Y, Kangawa K, Matsuo H, Omata M. 1999. Hypoxia-induced adrenomedullin production in kidney. Kidney Int 55:1259-1267.

Nakamura T, Matsumoto K. 1994. Growth factors: cell growth, morphogenesis and transformation. Tokyo: CRC Press.

Nakayama M, Takahashi K, Murakami O, Shirato K, Shibahara S. 1998. Induction of adrenomedullin by hypoxia and cobalt chloride in human colorectal carcinoma cells. Biochem Biophys Res Commun 243:514-517.

Nakayama N, Takahashi K, Murakami O, Shirato K, Shibahara S. 1999. Induction of adrenomedullin by hypoxia in cultured human coronary artery endothelial cells. Peptides 20:769-772.

Nguyen SV, Claycomb WC. 1999. Hypoxia regulates the expression of the adrenomedullin and HIF-1 genes in cultured HL-1 cardiomyocytes. Biochem Biophys Res Commun 265:382-386.

Nishikimi T, Horio T, Sasaki T, Yoshihara F, Takishita S, Miyata A, Matsuo H, Kangawa K. 1997. Cardiac production and secretion of adrenomedullin are increased in heart failure. Hypertension 30: $1369-1375$.

Nishimatsu H, Suzuki E, Nagata D, Moriyama N, Satonaka H, Walsh K, Sata M, Kangawa K, Matsuo H, Goto A, Kitamura T, Hirata Y. 2001. Adrenomedullin induces endothelium-dependent vasorelaxation via the phophatidylinositol 3-kinase/Akt-dependent pathway in rat aorta. Circ Res 89:63-70.

Nuki C, Kawasaki H, Kitamura K, Takenaga M, Kanqawa K, Eto T, Wada A. 1993. Vasodilator effect of adrenomedullin and calcitonin gene-related peptide receptors in rat mesenteric vascular beds. Biochem Biophys Res Commun 196:245-251.

Oehler MK, Norbury C, Hague S, Rees MCP, Bicknell R. 2001. Adrenomedullin inhibits hypoxic death by upregulation of Bcl-2 in endometrial cancer cells: a possible promotion mechanism for tumour growth. Oncogene 20:2937-2945.

Ogita T, Hashimoto E, Yamasaki M, Nakaoka T, Matsuoka R, Kira Y, Fujita T. 2001. Hypoxic induction of adrenomedullin in cultured human umbilical vein endothelial cells. J Hypertens 19:603-608.

Pangburn MK, Müller-Eberhard HJ. 1983. Kinetic and thermodynamic analysis of the control of $\mathrm{C} 3 \mathrm{~b}$ by the complement regulatory protein factors $\mathrm{H}$ and I. Biochemistry 22:178-185.

Parkes DG. 1995. Cardiovascular actions of adrenomedullin in conscious sheep. Am J Physiol (Heart Circ Physiol) 268:H2574-H2578.

Pío R, Martínez A, Unsworth EJ, Kowalak JA, Boengoechea JA, Zipfel PF, Elsasser T, Cuttitta F. 2001. Complement factor H is a serum binding protein for adrenomedullin, and the resulting complex modulates the bioactivity of both partners. J Biol Chem 276:1229212300 .

Piquard F, Charloux A, Mettauer B, Epailly E, Lonsdorfer E, Popescu S, Lonsdorfer J, Geny B. 2000. Exercise-induced increase in circulating adrenomedullin is related to mean blood pressure in heart transplant recipients. J Clin Endocrinol Metab 85:2828-2831.

Qing X, Svaren J, Keith IM. 2001. mRNA expression of novel CGRP1 receptors and their activity-modifying proteins in hypoxic rat lung. Am J Physiol (Lung Cell Mol Physiol) 280:L547-L554.

Rocchi P, Boudouresque F, Zamora AJ, Murocciole X, Lechevallier E, Martin P-M, Ouafik L'H. 2001. Expression of adrenomedullin and peptide amidation activity in human prostate cancer and human prostate cancer cell lines. Cancer Res 61:1196-1206.

Samson WK, Murphy TC, Schell DA. 1995. A novel vasoactive peptide, adrenomedullin, inhibits pituitary adrenocorticotropin release. Endocrinology 136:2349-2352.

Satoh F, Takahashi K, Murakami O, Totsune K, Sone M, Ohneda M, Abe K, Miura Y, Hayashi Y, Sasano H, Mouri T. 1995. Adrenomedullin in human brain, adrenal glands and tumor tissue of 
pheochromocytoma, ganglioneuroblastoma and neuroblastoma. J Clin Endocrinol Metab 80:1750-1752.

Semplicini A, Celolotto G, Baritono E, Malendowicz LK, Adreis PG, Sartori M, Rossi GP, Nussdorfer GG. 2001. Adrenomedullin stimulates DNA synthesis of rat adrenal zona glomerulosa cells through activated of the mitogen-activated protein kinase-dependent cascade. J Hypertens 19:599-602.

Shichiri M, Kato H, Doi M, Marumo F, Hirata Y. 1999. Induction of Max by adrenomedullin and calcitonin gene-related peptide antagonizes endothelial apoptosis. Mol Endocrinol 13:1353-1363.

Shimekake Y, Nagata K, Ohta S, Kambayashi Y, Ter H, Kitamura K, Eto T, Kangawa K, Matsuo H. 1995. Adrenomedullin stimulates two signal transduction pathways, cAMP accumulation and $\mathrm{Ca} 2+$ mobilization, in bovine aortic endothelial cells. J Biol Chem 270: $4412-4417$.

Shoji H, Minamino N, Kangawa K, Matsuo H. 1995. Endotoxin markedly elevates plasma concentration of gene transcript of adrenomedullin in rat. Biochem Biophys Res Commun 215:531-537.

Sugo S, Minamino NB, Shoji H, Kangawa K, Kitamura K, Eto T, Matsuo H. 1994. Production and secretion of adrenomedullin from vascular smooth muscle cells: augmented production by tumor necrosis factor- $\alpha$. Biochem Biophys Res Commun 201:719-726.

Sugo S, Minamino N, Shoji H, Kangawa K, Kitamura K, Eto T, Matsuo H. 1995. Interleukin-1, tumor necrosis factor and lipopolysaccharide activity stimulates production of adrenomedullin in vascular smooth muscle cells. Biochem Biophys Res Commun 207:2532

Takahashi K, Satoh F, Hara E, Sone M, Murakami O, Kayama T, Yoshimoto T, Shibahara S. 1997. Production and secretion of adrenomedullin from glial cell tumors and its effects on cAMP production. Peptides 18:1117-1124.

Tanaka M, Kitamura K, Ishizaka Y, Ishiyama Y, Kato J, Kangawa K, Eto J. 1995. Plasma adrenomedullin in various diseases and exercise-induced change in adrenomedullin in healthy subjects. Intern Med 34:728-733.

Tanimoto K, Makino, Pereira T, Poellinger L. 2000. Mechanism of regulation of the hypoxia-inducible factor- $1 \alpha$ by the von HippelLindau tumor suppressor protein. EMBO J 19:4298-4309.

Toepfer M, Hartman G, Schlosshauer M, Hautmann H, Tschöp M, Fischer R, Huber RM. 1998. Adrenomedullin: a player at high altitude? Chest 113:1428.

Udono T, Totsune K, Takahashi K, Abe T, Sato M, Shibahara S, Tamai M. 2000. Increased Expression of adrenomedullin mRNA in the tissue of intraocular and orbital tumors. Am J Ophthalmol 129:555-556

Udono T, Takahashi K, Nakayama M, Yoshinoya A, Totsune K, Murakami O, Durlu YK, Tamai M, Shibahara S. 2001. Induction of adrenomedullin by hypoxia in cultured retinal pigment epithelial cells. Invest Ophthalmol Vis Sci 42:1080-1086.

Uezono Y, Shibuya I, Ueda Y, Tanaka K, Oishi Y, Yanagihara N, Ueno S, Toyohira Y, Nakamura T, Yamashita H, Izumi F. 1998. Adrenomedullin increases intracellular $\mathrm{Ca} 2+$ and inositol 1,4,5trisphosphate in human oligodendroglial cell line KG-1C. Brain Res 786:230-234.

Walsh TJ, Martínez A, Peter J, Unsworth E, Cuttitta F. 1996. Antimicrobial activity of adrenomedullin and its gene related peptides. Clin Infect Dis 23:877 (Abstract 96).

Wang X, Yue T-L, Barone FC, White RF, Clark RK, Willette RN, Sulpizio AC, Aiyar NV, Ruffolo Jr RR, Feuerstein GZ. 1995. Discovery of adrenomedullin in rat ischemic cortex and evidence for its role in exacerbating focal brain ischemic damage. Proc Natl Acad Sci USA 92:11480-11484.

Wenger RH, Gassmann M. 1997. Oxygen(es) and the hypoxia-inducible factor-1. Biol Chem 378:609-616.

Withers DJ, Coppock HA, Seufferlein T, Smith DM, Bloom SR, Rozengurt E. 1996. Adrenomedullin stimulates DNA synthesis and cell proliferation via elevation of cAMP in Swiss 3T3 cells. FEBS Lett 378:83-87.

Zaks-Zilberman M, Salkowski CA, Elasser T, Cuttitta F, Vogel SN. 1998. Induction of adrenomedullin mRNA and protein by lipopolysaccharide and paclitaxel (taxol) in murine macrophage. Infect Immunol 66:4669-4675.

Zasloff M. 1987. Magainins, a class of antimicrobial peptides from Xenopus skin: isolation, characterization of two active forms and partial cDNA sequence of a precursor. Proc Natl Acad Sci USA 88:3952-3965.

Zhao L, Brown LA, Owji AA, Nenuz DJR, Smith DM, Ghatei MA, Bloom SR, Wilkins MR. 1996. Adrenomedullin activity in chronically hypoxic rat lungs. Am J Physiol (Heart Circ Physiol 40) 271: H622-H629.

Zhao Y, Hague S, Manek S, Zhang L, Bicknell R, Rees MCP. 1998. PCR display identifies tamoxifen induction of the novel angiogenic factor adrenomedullin by an non estrogenic mechanism in the human endometrium. Oncogene 16:409-415.

Zhong H, De Marzo AM, Laughner E, Lim M, Hilton DA, Zagzag D, Buechler P, Isaacs WB, Semenza GL, Simons JW. 1999. Overexpression of hypoxia-inducible factor- $1 \alpha$ in common human cancers and their metastases. Cancer Res 59:5830-5835.

Zimmermann U, Fischer JA, Muff R. 1995. Adrenomedullin and calcitonin gene-related peptide interact with the same receptor in cultured human neuroblastoma SK-N-MC cells. Peptides 16:421424 